\title{
Erratum
}

\section{Effects of face-to-face restorative justice on victims of crime in four randomized, controlled trials}

\author{
LAWRENCE W. SHERMAN, HEATHER STRANG*, CAROLINE ANGEL, \\ DANIEL WOODS, GEOFFREY C. BARNES, SARAH BENNETT, \\ NOVA INKPEN and MEREDITH ROSSNER \\ Jerry Lee Program on Randomized Controlled Trials in Restorative Justice, Jerry Lee Center \\ of Criminology, University of Pennsylvania, Philadelphia, Pennsylvania, USA \\ Centre for Restorative Justice, RegNet, Australian National University, Canberra, Australia \\ *corresponding author: Email: heather.strang@anu.edu.au
}

Two errors appeared in the article entitled 'Effects of face-to-face restorative justice on victims of crime in four randomized, controlled trials,' which appeared in the Journal of Experimental Criminology (2005) 1: 367-395:

1. The list of authors should have included Meredith Rossner, University of Pennsylvania

2. The Jerry Lee Program on Randomized Controlled Trials in Restorative Justice is located at the Jerry Lee Center of Criminology, University of Pennsylvania. 